1983;250:1978.

11. Fauerbach LL, Boeff D, Shands JW, Gutekunst RR. Product variance in PPD positivity rate. Infect Control H osp Epidemiol $1993 ; 14: 439$.

12. Lifson AR, Watters JK, Thompson S, Crane CM, Wise F. Discrepancies in tuberculin skin test results with two commercial products in a population of intravenous drug users. /Infect Dis 1993;168:1048-1051.
13. Tager IB, Kalaidjian R, Baldini L, Rocklin RE. Variability in the intradermal and in vitro lymphocyte responses to PPD in patients receiving isoniazid chemoprophylaxis. A m Rev Respir D is 1985;131:214-220.

14. Fagan MJ, Poland GA. Tuberculin skin testing in medical students: a survey of U.S. medical schools. Ann Intern M ed 1994;120:930-931.

\title{
CDC Reports Two Cases of HIV Transmission in Household Setting
}

by Gina Pugliese, RN, MS Medical News Editor

The Centers for Disease Control and Prevention (CDC) recently reported two cases of human immunodeficiency virus (HIV) infection that apparently occurred following mucocutaneous exposures to blood or other body substances in persons who received care from or provided care to HIV infected family members residing in the same household.

The first case involved a 5-year-old child whose parents were both HIV infected and who tested negative for HIV antibody in 1990 and July 1993 but tested positive in December 1993. From January through December 1993, the parents were the only known HIV infected persons with whom the child had any contact. The child lived with both parents until the father died as a result of acquired immunodeficiency syndrome (AIDS) in May 1993. The child continued to live with his mother, who had AIDS, until July 1993 and then lived in foster care. The child had several opportunities for contact with HIV infected blood. The mother had recurrent, purulent, exudative lesions (diagnosed as prurigo nodularis) on her face, neck, torso, buttocks, and extremities. She frequently scratched them until they bled, left the lesions uncovered, and discarded the gauze used to wipe the exudate onto the furniture or floor. In addition, the child intermittently had scabs from impetigo that the mother sometimes picked off and caused to bleed. Prior to the father's death the child sometimes used his father's toothbrush. HIV DNA analysis of the virus from the mother and the child revealed that the viruses were genetically similar.

The second case involved a 75-yearold woman who tested HIV positive in August 1991. Her adult son died in August 1990 as a result of AIDS. She had been married for 50 years and her husband tested negative for HIV She reported no other sex partners and denied all risk factors for HIV Her son lived in her household from September 1989 until he died in August 1990. In July 1990 , his mother began to provide daily nursing care for him (ie, bathing, feeding, changing diapers, repositioning his urinary catheter). She did not wear gloves and could not recall any direct exposures to her son's blood. The son did have one episode of upper gastrointestinal (GI) bleeding during hospitalization in February 1990 and an episode of lower GI bleeding during hospitalization in June 1990. No such bleeding was reported at home, however. There were no blood specimens available from the son for HIV DNA sequencing.

Although previous reports have documented HIV transmission as the result of skin or mucous membrane exposures to HIV-infected blood, HIV is not easily transmitted by this route. In both of these reports, exposure occurred after the source patients had developed AIDS; consequently, relatively high HIV titers may have been present in their blood.

Although contact with blood and other body substances can occur in households, transmission of HIV is rare in this setting. In addition to these two patients, six previous reports have described household transmission of HIV not associated with sexual contact, injecting drug use, or breastfeeding.

Persons who provide nursing care for HIV-infected patients in home settings should use precautions to reduce exposures to blood, body fluids, secretions, or excretions. This includes the use of gloves for contact with urine and feces because these substances may contain a variety of pathogens, including HIV. Additional infection control recommendations are contained in a recently updated brochure published by the CDC, Caring for Someone with AIDS: Information for Friends, Relatives, Household Members, and Others Who Care for a Person with AIDS at Home. This brochure is available from the CDC National AIDS Clearinghouse, P. 0. Box 6003, Rockville, MD 20849-6003; telephone (800) 458-5231.

FROM: Centers for Disease Control and Prevention. Human immunodeficiency virus transmission in household settings. M M WR 1994;43:347356. 